\title{
Efficacy of Zinc/Creatine Supplementation on Improving Growth Performance of Local Balady Chicks
}

\section{-Author(s)}

\section{Amer NSI'}

Hatab $\mathrm{MH}^{\prime}$

Sabic EM'

Biological Applications Department, Nuclear Research Center, Atomic Energy Authority, Egypt, P.O, Box 13759

\section{Mail Address}

Corresponding author e-mail address Nashat Saeid Ibrahim Amer

Biological Applic. Dep., Nuclear Res. Center, Atomic Energy Authority, Inshas, Abu-

zabel, Egypt, P.O, Box 13759.

Tel: (0202) 01119992240

Email: nashaat1977@yahoo.com

\section{aKeywords}

$\mathrm{Zn}$ and $\mathrm{CMH}$ supplementation, Balady chicks, performance, carcass characteristics, hematological, biochemical indices.

\section{ABSTRACT}

An experiment was designed to study the efficacy of Zinc and or creatine monohydrate $(\mathrm{CMH})$ supplementation, either alone or in combination, on improving growth performance of Balady chicks. A total number of 144 Balady chicks were randomly divided into four equal groups. The first treatment was fed the basal diet and served as control, while groups 2, 3, and 4 were given the basal diet and supplemented drinking water with, $0.6 \mathrm{mg} / \mathrm{ml}$ (zinc sulphat); $0.45 \mathrm{mg} / \mathrm{ml}(\mathrm{CMH}) ; 0.6$ $\mathrm{mg} / \mathrm{ml}$ (zinc sulphat) $+0.45 \mathrm{mg} / \mathrm{ml}(\mathrm{CMH})$, respectively. The results indicated that the live body weight, weekly body weight gain and feed efficiency were significantly $(p \leq 0.05)$ improved in all treated groups compared with the control. Also, significant decrease $(p \leq 0.05)$ has been recorded in water consumption values of treated groups compared to control. Moreover, significant increase was recorded in carcass yield, kidney, spleen, bursa, thymus and intestine density (weight/length) with treated groups as compared to control group. On the other hand, serum total protein, globulin, total lipids, total antioxidant, thyroxine hormone level were significantly higher in treated groups than the control. Furthermore, Red and white blood cell counts, hemoglobin level, hematocrit values and antibody titres against Newcastle disease virus, were significantly improved in all treated groups. Therefore, it can be concluded that $\mathrm{Zn}$ and or $\mathrm{CMH}$ supplementation improved the physiological, productive traits of Balady chicks. The best significant results of performance were recorded for group the supplemented with $\mathrm{Zn}$ and $\mathrm{CMH}$ in combination compared with those of other treatments.

\section{INTRODUCTION}

Poultry production plays the most important role in providing huge amounts and cheap source of animal protein in Egypt. A pure Egyptian breed, referred to as Balady local strains, is an animal resource which is established for both high quality meat and egg production, Taha et al. (2010). They are preferred to those produced by exotic hybrids and accepted by all consumers for a number of reasons, foremost being the degree of meat maturity, taste, texture and flavors, wholesome and more nutritious, Aymen et al. (2012). The higher premium prices of the Balady chicken are in part due to consumer preferrences and the limited scale of production. (Sonaiya \& Swan, 2004).

Unfortunately, Egyptian Balady local strains are of medium size, the adult live body weight averages $1.2-1.7 \mathrm{~kg}$ in 60-65 days, Aymen et al. (2012). Moreover, the FCR for the native breeds (about $3 \mathrm{~kg}$ of feed for each $\mathrm{kg}$ of live weight 1:3) is much higher than that for the imported exotic broiler strains (1:1.8) and the time taken by the native breeds to reach the marketing weight (60 to 80 days) is almost double the time required for the exotic strains to reach the market (35 to 42 days), Enaiat et al. (2010). In addition, there is limited attention to develop and improve the production performance of local chicks. 
The use of feed additives as well as zinc (Zn) and creatine monohydrate $(\mathrm{CMH})$ in broiler diets are becoming increasingly frequent to enhance growth performance. $\mathrm{Zn}$ is one of the essential trace elements that stimulate the activity of about 100 enzymes in the body, Bartlett \& Smith (2003). Zn is necessary for many physiological functions, including growth, skeletal development, immune function, sexual maturation, protein synthesis, gene expression, fat absorption, antioxidant defense, wound healing, improves appetite, metabolism of carbohydrates, proteins, lipids, skin health, and many essential biochemical processes of chickens, Suttle (2010). Hence, the body can't store $Z n$, so there may be a need to provide minimum daily intake. The NRC (1994) Zn requirement for broilers is 40 $\mathrm{mg} / \mathrm{kg}$. Zhao et al. (2014), suggested that appropriate concentrations of $\mathrm{Zn}$ resulted in improving the efficiency of feed utilization and growth performance in broilers. We hypothesized that $\mathrm{Zn}$ and/or $\mathrm{CMH}$ supplementation in drinking water as feed additives would elicit positive effects on growth performance of Egyptian Balady chicks when included in vegetable diet. $\mathrm{CMH}$ is another important feed additive in this study. It is certainly considered an excellent source of amino acids (arginine, glycine and methionine), Consequently, it can be used for poultry diets in comparatively small amounts as a main source of protein supplying feedstuff for better overall health status and to improve chicken production. Creatine is a naturally occurring component in the animal's body tissue and is mainly used in muscle tissues and plays an effective role in energy metabolism via phosphocreatine (PCr) system Wyss \& Daouk (2000). Hence, with the absence of animal protein free diet, the risk for creatine deficiency increased. It is likely that the requirement for creatine is proportionally superior in growing chicks than in adults due to the high rate of muscle and nerve growth that occurs. Moreover, all the processes of cells involved in growth and metabolism require energy. $\mathrm{CMH}$ supplementation is needed for mainly bodily functions concerning maintenance (i.e., ATP regeneration) and may be vital to support optimal growth (i.e., protein synthesis), Carvalho et al. (2013). Halle et al. (2006) showed that supplementing CMH up to $10 \mathrm{~g} / \mathrm{kg}$ diet can be regarded as a method for elevating production efficiency and meat yield in broiler chickens. Carvalho et al. (2013) also, reported that inclusion of $\mathrm{CMH}$ in the control diet also exerts an improvement in body weight gain and feed conversion ratio to broiler chicks compared with the diets with no $\mathrm{CMH}$.

Therefore, this study was designed to test the efficacy of $\mathrm{Zn}$ and/or $\mathrm{CMH}$ supplementation in improving growth performance and carcass characteristics of growing Balady chicks.

\section{MATERIALS AND METHODS}

\section{Location, birds and experimental design}

This experiment was carried out at the Poultry Production Research unit, belonging to the biological Application Department, Nuclear Research Center, Egyptian Atomic Energy Authority. A total number of 144 Balady chicks, as a local strain at 5 weeks of age and weighing $500 \mathrm{~g}$ on average, were randomly divided into four equal groups (36 birds in each group) with three replicates each. Each replicate contained ( 6 female and 6 cocks). The first treatment was fed the basal diet and served as control, while groups 2 , 3 , and 4 were given the basal diet and supplemented drinking water with, $0.6 \mathrm{mg} / \mathrm{ml}$ (zinc sulphate); 0.45 $\mathrm{mg} / \mathrm{ml}(\mathrm{CMH}) ; 0.6 \mathrm{mg} / \mathrm{ml}$ (zinc sulphate) $+0.45 \mathrm{mg} / \mathrm{ml}$ $(\mathrm{CMH})$, respectively. Each replicate was reared in cages of $80 \mathrm{~cm}$ width $\times 150 \mathrm{~cm}$ length $\times 50 \mathrm{~cm}$ height, to obtain stocking density of $\left(12 \mathrm{bird} / 1.2 \mathrm{~m}^{2}\right)$. This cage was provided with outdoor feeders and water supply equipment by nipple. All groups were kept under the same conditions of room temperature $25 \pm 2^{\circ} \mathrm{C}$ during the whole experimental period (5 weeks). $50 \pm 5 \%$ relative humidity $(\mathrm{RH})$, with a photoperiod of $14: 10(\mathrm{~L}$ : D) hours. The ingredient's composition and calculated chemical analysis of the basal diet are given in Table 1 .

Table 1 - The ingredient composition and calculated chemical analysis of the basal diet.

\begin{tabular}{lc}
\hline Ingredients composition & $\%$ \\
\hline Ground yellow corn 8.5\% & 61.5 \\
\hline Soybean meal (44\%) & 25 \\
Corn gluten meal (62\%) & 6 \\
Corn oil & 3 \\
Dicalcium. phosphate & 1.7 \\
Limestone & 1.5 \\
DL-methionine & 0.05 \\
Sodium chloride (NaCl) & 0.40 \\
L-Lysine-Hcl & 0.05 \\
Vitamin and Min. Mixture * & 0.3 \\
\hline Total & 100 \\
\hline Calculated chemical analysis & \\
Crude protein & 19.95 \\
Crude fiber & 1.7 \\
Crude fat & 2.68 \\
Calcium & 1.08 \\
Available phosphorous & 0.59 \\
Lysine & 0.85 \\
Methionine & 0.45 \\
Met+cystine & 0.34 \\
Metabolizable Energy & $3080.9 \mathrm{Kcal} / \mathrm{kg}$ \\
\hline
\end{tabular}

*Vitamin and mineral premix (contained per Kgm):- vit A, $1200 \mathrm{IU}$; vit D $1100 \mathrm{IU}$; vit E, 12mg; vitB12, 0.02mg; vit B1, 1mg; choline chloride, 0.16 mg; copper, 3mg; iron, 30mg; manganese, 40mg; zinc, $45 \mathrm{mg}$; and selenium, $3 \mathrm{mg}$. 


\section{Measurements and collected data}

\section{Growth performance parameters}

Growth performance parameters were measured on Balady chicks at 6, 7, 8, 9 and 10 weeks of age. The average body weight gain (BWG), feed consumption (FC), Water consumption (WC) and feed efficiency (FE) were calculated every week on a pen basis for each treatment during the experiment period (5 weeks). Feed conversion ratio (FCR) was also calculated within each replicate as the ratio of feed intake (FI) to BWG ( $g$ $\mathrm{feed} / \mathrm{g}$ gain) at the end of each week.

\section{Carcass traits and blood analysis}

At the end of the experimental period ( 5 weeks of age), four birds per experimental unit (i.e., 12 birds per treatment), with body weights close to the group mean, were weighed and slaughtered for carcass analysis. Carcass, liver, heart, proventriculus, gastrointestinal tract, spleen, and bursa of Fabricius for each slaughter bird were determined as a relative percentage of live body weight. In addition, gastrointestinal tract length was determined. Blood samples were collected from slaughtered birds in two tubes, one with heparin and the other without anticoagulant which centrifuged at $3400 \times g$ for 6 min to obtain sera, and then were stored at $-20^{\circ} \mathrm{C}$ until further analysis.

The concentrations of serum total proteins, albumin, total antioxidant, triglyceride, and total cholesterol and the activities of alkaline phosphates (ALP), alanine aminotransferase (ALT), and aspartate aminotransferase (AST), were measured with a spectrophotometer (Shimadzu UV 1601) using commercial kits produced by Stanbio Company, USA.

Serum Globulin values were calculated by subtracting albumin values from their corresponding total proteins values of the same sample.

Concerning blood hematological parameters, red blood cells (RBCs) and white blood cells (WBCs), counts were performed using hemocytometer and Natt and Herrick solution according to Harrison and Harrison (1986). The packed cell volume (PCV \%) was estimated by microhematocrit centrifuge according to Coles (1986). Hemoglobin concentration ( $\mathrm{Hb}$ ) was determined according to Dacie and Lewis (1991). The Thyroxin (T4) hormone concentration was determined using radioimmunoassay (RIA) Commercial Kit produced by IZOTOP Company (INSTITUTE OF ISOTOPES Ltd.) (http://www.izotop.hu), and samples were counted on Packard Gamma Counter.

\section{Immunological test}

At the end of the experiment, six birds from each group were chosen at random and housed in batteries. Each bird was vaccinated against Newcastle disease with NDV clone 30 (Nobilis ND Clone 30; Intervet) by eye-drop. Blood samples were withdrawn from jugular vein using an insulin syringe at three times 3, 7 and 9 days of post-vaccination. Blood was allowed to clot then centrifuged immediately to separate serum to determine immune response (antibody titer) of the chickens derived from vaccination against Newcastle disease virus by performing Hemagglutination inhibition (HI) test on serum samples according to the method of King \& Seal (1998).

\section{Statistical analysis}

The experiment was performed as a completely randomized design with 4 treatments. Statistical analyses were performed using the GLM procedure of JMP SAS (2008). The pen served as the experimental unit for the growth performance parameters (i.e., BWG, $F C, F E, W C$ and $F C R$ ) and other parameters (i.e., serum biochemical). An arc-sin transformation was applied to the percentage values (i.e., carcass and some organs) before testing for differences. Tukey's multiple range test was performed to detect differences among the treatments. All differences were considered significant at $p \leq 0.05$.

\section{RESULTS AND DISCUSSION}

\section{Growth Performance Parameters}

Effect of $\mathrm{Zn}$ and/or CMH supplementation on growth performance and feed efficiency parameters of Balady chicks are presented in Table (2 and 3). It was observed that $\mathrm{Zn}$ and/or $\mathrm{CMH}$ supplementation improved total gain, feed conversion ratio and feed efficiency over the entire 5-wk experimental period when compared with the control group. Total feed

Table 2 - Live body weight gain ( $\mathrm{g} / \mathrm{bird} /$ week) as affected by $\mathrm{Zn}$ and or creatine supplementation (mean \pm se) in Balady chicks

\begin{tabular}{lcccc}
\hline Live Body & \multicolumn{4}{c}{ Experimental groups } \\
\cline { 2 - 5 } $\begin{array}{l}\text { weight gain } \\
\text { (g/bird/week) }\end{array}$ & Control & Zn & Creatine & Zn \&Creatine \\
\hline $1^{\text {st }}$ week & $112.5 \pm 5.9^{\mathrm{d}}$ & $120.7 \pm 6.7^{\mathrm{c}}$ & $133.3 \pm 6.9^{\mathrm{b}}$ & $147.7 \pm 6.7^{\mathrm{a}}$ \\
\hline $2^{\text {nd }}$ week & $100 \pm 6.2^{\mathrm{c}}$ & $106 \pm 6.7^{\mathrm{b}}$ & $110 \pm 7.9^{\mathrm{b}}$ & $134 \pm 7.8^{\mathrm{a}}$ \\
$3^{\text {rd }}$ week & $86.3 \pm 2.8^{\mathrm{c}}$ & $103.6 \pm 4.1^{\mathrm{b}}$ & $108.2 \pm 6.1^{\mathrm{b}}$ & $126.3 \pm 4.1^{\mathrm{a}}$ \\
$4^{\text {th }}$ week & $85.7 \pm 3.2^{\mathrm{d}}$ & $95.5 \pm 2.1^{\mathrm{b}}$ & $102.6 \pm 3.4^{\mathrm{b}}$ & $112.6 \pm 3.3^{\mathrm{a}}$ \\
$5^{\text {th }}$ week & $80.3 \pm 5.6^{\mathrm{d}}$ & $110.3 \pm 5.2^{\mathrm{c}}$ & $117.3 \pm 4.9^{\mathrm{b}}$ & $141.7 \pm 4.2^{\mathrm{a}}$ \\
\hline
\end{tabular}

$a, b, c$ means with different superscripts within the same row are significantly different at $(p \leq 0.05)$. 
Table 3 - Growth and feed performance as affected by Zn and or creatine supplementation in Balady chicks (mean \pm se) at 70 days of age

\begin{tabular}{|c|c|c|c|c|c|}
\hline \multirow{2}{*}{ Growth performance } & \multirow{2}{*}{ sex } & \multicolumn{4}{|c|}{ Experimental groups } \\
\hline & & Control & $\mathrm{Zn}$ & Creatine & Zn \&Creatine \\
\hline \multirow{3}{*}{ Initial live body weight (g) } & Male & $678.3 \pm 0.5^{a}$ & $678.2 \pm 0.4^{a}$ & $670.5 \pm 0.48^{a}$ & $671.0 \pm 0.5^{\text {a }}$ \\
\hline & Female & $494.0 \pm 0.5^{a}$ & $495.8 \pm 0.4^{a}$ & $502.6 \pm 0.5^{a}$ & $497.4 \pm 0.49^{a}$ \\
\hline & Mean & $586.1 \pm 0.5^{a}$ & $587.2 \pm 0.4^{a}$ & $586.6 \pm 0.5^{a}$ & $584.2 \pm 0.5^{a}$ \\
\hline \multirow{3}{*}{ Final live body weight $(\mathrm{g})$ at $5^{\text {th }}$ week } & Male & $1190 \pm 1.45^{d}$ & $1270 \pm 1.66^{c}$ & $1317 \pm 0.88^{b}$ & $1428 \pm 1.66^{a}$ \\
\hline & Female & $909 \pm 1.66^{c}$ & $972 \pm 2.08^{b}$ & $995 \pm 1.85^{a}$ & $1062 \pm 2.89^{a}$ \\
\hline & Mean & $1049.5 \pm 7.6^{c}$ & $1121 \pm 5.2^{b}$ & $1156 \pm 4.9^{b}$ & $1245 \pm 4.2^{\mathrm{a}}$ \\
\hline Daily weight gain (g) & & $13.29 \pm 1.5^{d}$ & $15.32 \pm 1.4^{c}$ & $16.33 \pm 1.4^{b}$ & $18.92 \pm 0.8^{a}$ \\
\hline Daily Feed intake (g./bird) & & $45.9 \pm 1.3^{a}$ & $44.0 \pm 0.9^{b}$ & $41.6 \pm 1.2^{c}$ & $39.5 \pm 0.9^{c}$ \\
\hline Feed consumption(g)/bird & & $1606.5 \pm 2.3^{a}$ & $1540 \pm 2.3^{b}$ & $1456 \pm 2.3^{c}$ & $1382.5 \pm 2.3^{d}$ \\
\hline Feed conversion ratio (feed : gain) & & $3.45 \pm 0.1^{\mathrm{a}}$ & $2.87 \pm 0.1^{\mathrm{b}}$ & $2.55 \pm 0.09^{c}$ & $2.09 \pm 0.09^{d}$ \\
\hline $\begin{array}{l}\text { Feed efficiency ratio } \\
\text { (gain : feed) }\end{array}$ & & $0.29 \pm 0.1^{d}$ & $0.35 \pm 0.1^{c}$ & $0.39 \pm 0.09^{b}$ & $0.48 \pm 0.09^{a}$ \\
\hline \multicolumn{6}{|l|}{ Feed intake (g)/bird } \\
\hline $1^{\text {st }}$ week & & $57.1 \pm 0.37^{a}$ & $54.9 \pm 0.33^{b}$ & $52.8 \pm 0.32^{c}$ & $48.2 \pm 0.37^{d}$ \\
\hline $2^{\text {nd }}$ week & & $60.6 \pm 0.33^{a}$ & $58.3 \pm 0.32^{b}$ & $54.01 \pm 0.49^{c}$ & $50.3 \pm 0.33^{d}$ \\
\hline $3^{\text {rd }}$ week & & $64.9 \pm 0.39^{a}$ & $61.74 \pm 0.33^{b}$ & $59.22 \pm 0.49^{c}$ & $55.7 \pm 0.53^{d}$ \\
\hline $4^{\text {th }}$ week & & $67.4 \pm 0.37^{a}$ & $64.67 \pm 0.19^{b}$ & $62.77 \pm 0.18^{c}$ & $59.1 \pm 0.32^{d}$ \\
\hline $5^{\text {th }}$ week & & $71.3 \pm 0.48^{a}$ & $68.3 \pm 0.38^{b}$ & $63.7 \pm 0.32^{c}$ & $63.3 \pm 0.74^{c}$ \\
\hline
\end{tabular}

$a, b, c$ means with different superscripts within the same row are significantly different at $(p \leq 0.05)$.

intake of Balady chicks was reduced with $\mathrm{Zn}$ and/or $\mathrm{CMH}$ supplementation resulting in a $4.1 \%, 9.3 \%$ and $13.94 \%$ respectively lower feed intake compared with the control one. Moreover, combination of $\mathrm{Zn}$ and $\mathrm{CMH}$ showed better results of the tested parameters than $\mathrm{CMH}$ or $\mathrm{Zn}$ supplementation each alone, respectively. These findings are in agreement with several reports demonstrating that $\mathrm{CMH}$ supplemented up to $10 \mathrm{~g} /$ $\mathrm{kg}$ diet of the broilers improved the body weight gains compared with the same diet without the use of the additive, Carvalho et al. (2013). Similarly, Fawzy et al. (2016) showed also that body weight gain of the birds fed with the diet supplemented with Zn (2 g /10 $\mathrm{kg}$ ration) were significantly higher than the control group and the feed conversion ratio was better. On the other hand, consistent with these results, a number of researchers documented that growth rate and feed efficiency were improved by dietary Zn supplementation in broiler chicks Zhao et al. (2014) \& Fazilati (2013). Fathi et al. (2016) also, showed that nano-ZnO supplemented $20 \mathrm{mg} / \mathrm{kg}$ diet of the broilers improved the body weight gains and decreased feed intake compared with the control group. In addition, Bahakaim et al. (2014) noted a significant decrease in feed intake with the two levels 50 and $150 \mathrm{mg}$ supplemental Zn $/ \mathrm{kg}$ diet of chicken. The improvement in the Growth Performance Parameters of birds supplemented $\mathrm{Zn}$ and/or $\mathrm{CMH}$ could be attributed to the mandatory role of $\mathrm{Zn}$ as cofactor for more than 300 enzymes, which is essential in many digestive, metabolic and physiological processes in the body which reflect on growth, protein and carbohydrate metabolism. In this regard, the positive effect of Zn supplementation in drinking water on FCR may be due to the improvement in nutrient digestibility and efficiency of its use and therefore, decreased FC and improved FCR. Moreover, Zn plays a protective role on pancreatic tissue against oxidative damage, it may help the pancreas to function properly including secretions of digestive enzymes, thus improving digestibility of nutrients and consequently, performance Park et al. (2004).

$\mathrm{Zn}$ is a known essentially as a micronutrient for the growth of broilers. In the present study it was observed that appropriate levels of $\mathrm{Zn}(0.6 \mathrm{mg} / \mathrm{ml})$, improved body weight gain and presented a better feed conversion ratio compared with other groups. The significant reduction observed in FC of this study may be due to the role of $\mathrm{Zn}$ which involves control of appetite. Sahraei et al. (2013), reported that Zn deficiency results in reduced appetite and depressed growth.

$\mathrm{CMH}$, also, a compound based on three amino acids (arginine, glycine, and methionine), may be involved in this subject because it is a critical precursor in the production of muscle energy. The results of using $0.45 \mathrm{mg} / \mathrm{ml}(\mathrm{CMH})$ were in line with those of Zn supplementation, where BWG and FCR were improved in such supplement compared with an unsupplemented group. CMH may enhance muscle performance, growth and protein synthesis, due to an increase in the amount of energy stored as $\mathrm{PCr}$ in 


\section{Efficacy of Zinc/Creatine Supplementation on Improving Growth Performance of Local Balady Chicks}

muscle. Earlier research has suggested that $\mathrm{CMH}$ can help the body quickly provide adenosine triphosphate (ATP) through the phosphocreatine. In addition, $\mathrm{CMH}$ loaded muscle has the capacity to maintain normal physiological function and to delay the onset of muscle fatigue, Lindahl et al. (2006). These observations provide clear and direct evidence of $\mathrm{CMH}$ efficacy in terms of growth performance and muscle phosphagen status in growing Balady chicks fed vegetable diets.

\section{Water consumption}

The water consumption data was summarized in Table 4. This study showed that, $\mathrm{Zn}$ and/or $\mathrm{CMH}$ supplementation decreased water consumption when compared with the control group. Moreover, $\mathrm{Zn}$ and
$\mathrm{CMH}$ supplementation together, showed lower results of the water consumption than other groups. It seems reasonable because of the reduction of caloric consumption per $\mathrm{kg}$ of BWG in groups supplemented with $\mathrm{Zn}$ and /or CMH. Lemme et al. (2010) showed that $\mathrm{Zn}$ and/or $\mathrm{CMH}$ play central roles in energy metabolism. Mousavi et al. (2013) also, showed that $\mathrm{CMH}$ supplementation decreased caloric intake per kilogram of BW gain and per kilogram of carcass weight. $\mathrm{CMH}$ supplementation is likely alleviating the muscle concentrations of creatine related metabolites as found by Guimaraes (2014). In this way, PCr concentrations increase the overall potential for muscle energy homeostasis as illustrated by Guimaraes (2014), thereby allowing for ATP to be consumed at a higher

Table 4 - Water consumption (ml)/bird as affected by Zn and or creatine supplementation in Balady chicks (mean \pm se)

\begin{tabular}{lcccc}
\hline \multirow{2}{*}{ Water consumption ml/bird } & \multicolumn{3}{c}{ Experimental groups } \\
\cline { 2 - 5 } & Control & Zn & Creatine & Zn \&Creatine \\
\hline $1^{\text {st }}$ week & $137.03 \pm 1.8^{\mathrm{a}}$ & $135.2 \pm 1.85^{\mathrm{a}}$ & $125.9 \pm 1.85^{\mathrm{b}}$ & $111.1 \pm 5.5^{\mathrm{c}}$ \\
$2^{\text {nd }}$ week & $140.7 \pm 1.85^{\mathrm{a}}$ & $135.2 \pm 1.85^{\mathrm{a}}$ & $137.03 \pm 1.85^{\mathrm{a}}$ & $120.4 \pm 1.85^{\mathrm{b}}$ \\
$3^{\text {rd }}$ week & $175 \pm 1.61^{\mathrm{a}}$ & $163.3 \pm 1.7^{\mathrm{b}}$ & $146.1 \pm 3.47^{\mathrm{c}}$ & $157.4 \pm 3.7^{\mathrm{b}}$ \\
$4^{\text {th }}$ week & $196.3 \pm 1.85^{\mathrm{a}}$ & $168.5 \pm 0.98^{\mathrm{b}}$ & $168.5 \pm 1.85^{\mathrm{b}}$ & $153.7 \pm 1.85^{\mathrm{c}}$ \\
$5^{\text {th }}$ week & $218.5 \pm 3.7^{\mathrm{a}}$ & $201.8 \pm 1.85^{\mathrm{b}}$ & $207.5 \pm 3.7^{\mathrm{b}}$ & $177.7 \pm 3.2^{\mathrm{c}}$ \\
\hline
\end{tabular}

$a, b, c$, means with different superscripts within the same row are significantly different at $(p \leq 0.05)$.

rate in support of improved metabolic function, this phenomenon has been purported to increase the rate of muscle protein synthesis Dilger et al. (2013) which might be beneficial for both skeletal muscle growth and for contractile activity of supply organs, such as the heart. Another benefit might arise from the fact that intramuscular $\mathrm{PCr}$ promotes water retention, it can attract water into the muscle cell and increase the cell volume as found by Guimaraes (2014) and this effect of super hydrated muscle may trigger protein synthesis, minimize protein breakdown, and increase glycogen synthesis in the muscle, this process may also support muscle growth as well, and may be illustrated the anabolic effects of creatine supplementation in birds. Unfortunately, the muscle volume and water content were not analyzed in this study. The current experiment's results concluded that $\mathrm{Zn}$ and/or $\mathrm{CMH}$ supplementation has the potential to improve the FCR and energy efficiency of growing Balady chicks.

\section{Carcass traits and relative organ weights}

The results of carcass traits and relative organ weights are given in Table 5 . The relative weight of carcass was significantly increased in chicks treated

Table 5 - Relative weight of carcass and some organs as affected by $\mathrm{Zn}$ and or creatine supplementation in Balady chicks (mean \pm se) at 70 days of age

\begin{tabular}{|c|c|c|c|c|}
\hline \multirow[t]{2}{*}{ Relative weight of carcass and some organs $(\mathrm{g})$} & \multicolumn{4}{|c|}{ Experimental groups } \\
\hline & Control & $\mathrm{Zn}$ & Creatine & Zn \&Creatine \\
\hline Live body weight & $1049 \pm 1.45^{d}$ & $1121 \pm 1.66^{c}$ & $1156 \pm 0.88^{b}$ & $1245 \pm 1.66^{\mathrm{a}}$ \\
\hline Carcass & $62.12 \pm 1.6^{b}$ & $66.47 \pm 0.25^{a}$ & $65.99 \pm 0.65^{a}$ & $66.47 \pm 1.05^{\text {a }}$ \\
\hline Liver & $2.1 \pm 0.16^{\mathrm{a}}$ & $2.1 \pm 0.14^{\mathrm{a}}$ & $1.9 \pm 0.07^{a}$ & $1.9 \pm 0.07^{a}$ \\
\hline Gizzard & $2.1 \pm 0.21^{\mathrm{a}}$ & $1.9 \pm 0.18^{a}$ & $2 \pm 0.15^{a}$ & $1.9 \pm 0.16^{\mathrm{a}}$ \\
\hline Kidney & $0.64 \pm 0.08^{b}$ & $0.73 \pm 0.01^{\text {a }}$ & $0.71 \pm 0.03^{\mathrm{a}}$ & $0.61 \pm 0.06^{b}$ \\
\hline Proventriculus & $0.4 \pm 0.06^{a}$ & $0.41 \pm 0.05^{a}$ & $0.42 \pm 0.04^{a}$ & $0.41 \pm 0.02^{\mathrm{a}}$ \\
\hline Spleen & $0.22 \pm 0.03^{b}$ & $0.26 \pm 0.03^{a}$ & $0.24 \pm 0.01^{\mathrm{a}}$ & $0.25 \pm 0.03^{a}$ \\
\hline Bursa & $0.33 \pm 0.1^{b}$ & $0.38 \pm 0.05^{a}$ & $0.37 \pm 0.02^{\mathrm{a}}$ & $0.33 \pm 0.06^{b}$ \\
\hline Thymus & $0.4 \pm 0.07^{a}$ & $0.335 \pm 0.07^{a}$ & $0.37 \pm 0.04^{\mathrm{a}}$ & $0.33 \pm 0.045^{a}$ \\
\hline Heart & $0.48 \pm 0.01^{b}$ & $0.52 \pm 0.02^{a}$ & $0.475 \pm 0.007^{b}$ & $0.445 \pm 0.01^{c}$ \\
\hline Small intestine density (weight/ length) & $1.6 \pm 0.03^{b}$ & $1.8 \pm 0.02^{\mathrm{a}}$ & $1.6 \pm 0.03^{b}$ & $1.9 \pm 0.05^{\mathrm{a}}$ \\
\hline
\end{tabular}

$a, b, c$, means with different superscripts within the same row are statistically different at $(p \leq 0.05)$. 
with $\mathrm{Zn}$ and $\mathrm{CMH}$ either alone or together as compared to the control. Meanwhile, no significant differences were observed in the relative weight of liver, gizzard and proventriculus among the treatment groups. However, Mousavi et al. (2013) showed that, the addition of $0.06 \% \mathrm{CMH}$ reduced the percentage of liver significantly. Moreover, kidney relative weight was significantly increased in chicks treated with Zn or $\mathrm{CMH}$ each alone as compared to the other groups. The above result indicated that $\mathrm{Zn}$ or $\mathrm{CMH}$ supplementation did not induced hepatic and renal malfunction.

In the same trend, heart relative weight was increased in chicks treated with $\mathrm{Zn}$ as compared to the other groups. However, $\mathrm{Zn}$ and $\mathrm{CMH}$ in combination showed the lowest result of the relative weight of heart among groups. The results proved that $\mathrm{Zn}$ had significant influence on bird's antioxidant status, hematopoietic system responsibility and growth performance, birds with Zn supplementation in drinking water maintained their antioxidant systems in the heart muscle more effectively, with enhanced antioxidant defense.

The relative weights of lymphoid organs as (spleen and bursa of Fabricius) were increased by the supplemented $\mathrm{Zn}$ and or $\mathrm{CMH}$ with no significant effects on the relative weights of thymus. The significant increase in the relative weight of the bursa of Fabricius may be attributed to the increase of the number of immune cells, which is due to the effect of $\mathrm{Zn}$ and or $\mathrm{CMH}$ on the functional activities of the immune system responses which led to the increase in the number of lymphocytes in the primary lymphoid organs. Immune organ weight estimation is a common method for immune status evaluation of birds Heckert et al. (2002). Such related organs include thymus, bursa of Fabricius, liver and spleen. Good development of these organs is crucial for optimal lg synthesis. Therefore, beneficial effects of $\mathrm{Zn}$ and or $\mathrm{CMH}$ supplementation in the gastrointestinal tract could result in an improvement of overall health, performance and immune response of layer chicks. These findings were similar to those observed by Sunder et al. (2008) and disagreed with Osman \& Ragab (2007), who reported that supplementation of broiler chicks with $\mathrm{Zn}$ did not affect the relative weights of bursa, spleen and thymus. In poultry, $\mathrm{Zn}$ is responsible for the activation of the antioxidant status Prasad (2008) and immune system of the bird as a result of increasing the natural killer cell, thymocytes and peripheral T cell counts. Also it stimulates neutrophils and antibodies production. Moreover, Park et al. (2004) showed the role of Zn in supporting superior humoral, cell mediated responses and improving the macrophage functions.

The small intestine density (weight/ length), as shown in Table 5, significantly increased in chicks treated with $\mathrm{Zn}$ either alone or in combination with $\mathrm{CMH}$ as compared to the other groups. This is in line with observations by Lemme et al. (2010) and might be due to improving the cell energy metabolism because supplemental $\mathrm{CMH}$ increased the muscle creatine content and some metabolites correlated with the energy homeostasis such as PCr and ATP. Such changes might improve the utilization of nutrients for muscle accretion and growth and thus feed utilization. Mousavi et al. (2013) reported that the weight of the small intestine was reduced in the low-energy (90\%) diets supplemented with $\mathrm{CMH}$. Supplementation with $\mathrm{CMH}$ decreased caloric intake per kilogram of BW gain and per kilogram of carcass weight.

\section{Hematological Responses}

The effect of $\mathrm{Zn}$ and or $\mathrm{CMH}$ supplementation on the hematological parameters of Balady chicks are presented in Table 6. These results indicated that, $\mathrm{Zn}$ and or $\mathrm{CMH}$ supplementation have significant effect on the level of $\mathrm{Hb}, \mathrm{PCV}, \mathrm{WBC}$ s and RBC's count in treated groups when compared with the control group. Our results parallel to the study conducted by Sajadifar (2012), who showed that Zn supplementation up to $200 \mathrm{mg} / \mathrm{kg}$ diet significantly increased the total WBCs of broiler chicks in compare with control group. Also, several researchers observed better immune response with increasing the level of $\mathrm{Zn}$ supplementation, Ezzati et al. (2013). However, this finding disagreed with Donmez et al. (2001), who reported that Zn

Table 6 - Blood hematology levels (mean \pm se) as affected by $\mathrm{Zn}$ and or creatine supplementation in Balady chicks at 70 days of age

\begin{tabular}{|c|c|c|c|c|}
\hline \multirow{2}{*}{ Trails } & \multicolumn{4}{|c|}{ Experimental groups } \\
\hline & Control & $\mathrm{Zn}$ & Creatine & Zn \&Creatine \\
\hline RBCs Count $\times 10^{6}$ & $4.13 \pm 0.06^{c}$ & $4.3 \pm 0.07^{b}$ & $4.67 \pm 0.05^{a}$ & $4.45 \pm 0.03^{b}$ \\
\hline $\mathrm{Hb}(\mathrm{g} / \mathrm{dl})$ & $22.4 \pm 0.3^{c}$ & $23 \pm 0.1^{b}$ & $24 \pm 0.15^{a}$ & $23 \pm 0.1^{b}$ \\
\hline PCV \% & $83.6 \pm 0.4^{b}$ & $85.9 \pm 0.2^{a}$ & $85.5 \pm 0.1^{\mathrm{a}}$ & $85.6 \pm 0.5^{a}$ \\
\hline WBCs Count $\times 10^{3}$ & $279.9 \pm 7.4^{b}$ & $349.9 \pm 6.3^{a}$ & $344.7 \pm 4.9^{a}$ & $347.5 \pm 5.8^{a}$ \\
\hline
\end{tabular}

$a, b, c$, means with different superscripts within the same row are significantly different at $(p \leq 0.05)$. 


\section{Efficacy of Zinc/Creatine Supplementation on Improving Growth Performance of Local Balady Chicks}

supplementation did not affect peripheral blood leukocyte counts. It seems that $Z n$ supplementation of broilers increased lymphocyte and proliferation in visceral blood, Yang et al. (2011). Moreover, Zn plays an important role in immunomodulation by increasing the counts of thymocytes, peripheral $\mathrm{T}$ cells and enhancing the interferon production. Zn increases the $T$ and $B$ lymphocytes and enhances the immune responses of birds, Hudson et al. (2004). Our leukogram results, Table 6 , are identical to the theory that $\mathrm{Zn}$ has an effective role in optimizing immune response, innate and acquired immune systems in chicks. Moreover, it has a role in increasing the antioxidant enzymes activities in the present study. Furthermore, the addition of $\mathrm{Zn}$ to poultry ration increased the hematopoietic system activity due to the increase of serum $\mathrm{Zn}$ level which stabilizes and regulates the cell membranes functions and protects it from lipid peroxidation Gruber \& Rink (2013). CMH also increased the hematological parameters of Balady chicks because $\mathrm{CMH}$ is involved in energy production from the inner mitochondria to the cytosol. $\mathrm{CMH}$ supplementation has been shown to be beneficial in diseases in which there is mitochondrial dysfunction such as encephalopathy, Parkinson's, myopathy and lactic acidosis, Persky \& Brazeau (2001). These results would be explained as the supplementation of $\mathrm{Zn}$ and or $\mathrm{CMH}$ affecting positively blood- cell forming processes. Moreover, increased blood WBCs count might be related to the production of more immune cells that play an important role in defending the biological system against different diseases.

\section{Immune response}

In the present study, attempts were made to evaluate the use of $\mathrm{Zn}$ and or CAM as feed supplements for antimicrobials and antiviruses in terms of their ability to improve disease resistance, and enhance overall health and production in poultry.

Serum antibody titers against Newcastle disease virus-based on $\mathrm{HI}$ test in treated chicks with $\mathrm{Zn}$ and or CAM supplementation showed a higher response $(p \leq 0.05)$ than those of chicks in control group on days 3, 7 and 9 post vaccination, Table 7. Moreover, chicks treated with $\mathrm{Zn}$ alone and in combination with CAM were similar and significantly increased the

Table 7 - Antibody titres to Newcastle disease virus as affected by Zn and or creatine supplementation in Balady chicken (mean \pm se) at 70 days of age

\begin{tabular}{|c|c|c|c|c|}
\hline \multirow{3}{*}{ Days of treatment } & \multicolumn{4}{|c|}{ Antibody titres against Newcastle disease virus } \\
\hline & \multicolumn{4}{|c|}{ Experimental groups } \\
\hline & Control & $\mathrm{Zn}$ & Creatine & Zn \&Creatine \\
\hline $3^{\text {rd }}$ day & $3.75 \pm 0.25^{b}$ & $5.25 \pm 0.25^{a}$ & $4.5 \pm 0.29^{a b}$ & $5.25 \pm 0.25^{a}$ \\
\hline $7^{\text {th }}$ day & $5.25 \pm 0.25^{c}$ & $8.25 \pm 0.25^{a}$ & $7.25 \pm 0.25^{b}$ & $8.25 \pm 0.25^{a}$ \\
\hline $9^{\text {th }}$ day & $4.25 \pm 0.25^{b}$ & $6.75 \pm 0.475^{a}$ & $5.75 \pm 0.25^{a}$ & $6.75 \pm 0.475^{a}$ \\
\hline
\end{tabular}

$a, b, c$, Means in the same row with different superscripts are significantly different $(p \leq 0.05)$.

antibody titer against NDV, higher than chicks treated with CAM alone. These findings are in agreement with several studies. Sajadifar (2012) showed that Zn supplementation up to $200 \mathrm{mg} / \mathrm{kg}$ diet significantly increased the antibody titer against NDV and total WBCs of broiler chicks in comparison to the control group. Bartlett and Smith (2003) reported that the broilers receiving up to $181 \mathrm{mg} \mathrm{Zn}$ had a higher response for total, IgM, and IgG antibodies. Feng et al. (2010) and Hudson et al. (2004) observed higher cellular immune response and antibody titers against Newcastle disease in broiler fed diets supplemented with $90 \mathrm{mg} \mathrm{Zn/kg}$ as Zn-gly compared to $160 \mathrm{mg} \mathrm{Zn/}$ $\mathrm{kg}$ as $\mathrm{ZnSO} 4$.

$\mathrm{Zn}$ is necessary to maintain the activity of natural killer cells and phagocytosis of macrophages, Gruber \& Rink (2013). The overall serological data of this study showed that both $\mathrm{Zn}$ and or CAM supplementation seems to increase antibody titer against NDV and total WBCs. Thus, supplementing $\mathrm{Zn}$ and or CAM in broiler's drinking water could be considered as a natural promoter of immune system against diseases and increase of poultry's resistance.

\section{Biochemical and hormonal parameters}

The effects of $\mathrm{Zn}$ and or CAM supplementation on some plasma biochemical and hormonal parameters (Means $\pm \mathrm{SE}$ ) are presented in Table 8 . The data clearly showed that protein profile: plasma total protein, albumin and globulin were significantly increased in treated groups when compared with the control.

Protein profile in Balady chicks supplemented with $\mathrm{Zn}$ and or $\mathrm{CMH}$ showed an elevation in total proteins, albumin, and globulin levels. Similarly, plasma total protein was increased with Zn dietary supplementation in broiler. Feng et al. (2010) and Fawzy et al. (2016), found an elevation in total protein, albumin, and globulin levels in broilers chicks supplemented with Zn 


\section{Efficacy of Zinc/Creatine Supplementation on Improving Growth Performance of Local Balady Chicks}

Table 8 - Serum constituents and hormonal levels as affected by $\mathrm{Zn}$ and or creatine supplementation in Balady chicken (mean \pm se) at 70 days of age

\begin{tabular}{|c|c|c|c|c|}
\hline \multirow{2}{*}{ Parameters } & \multicolumn{4}{|c|}{ Experimental groups } \\
\hline & Control & $\mathrm{Zn}$ & Creatine & Zn \&Creatine \\
\hline Total protein $(\mathrm{g} / \mathrm{dl})$ & $4.2 \pm 0.05^{b}$ & $4.57 \pm 0.03^{a}$ & $4.56 \pm 0.04^{a}$ & $4.4 \pm 0.04^{a}$ \\
\hline Albumin(g/dl) & $2.83 \pm 0.04^{b}$ & $3.04 \pm 0.04^{\mathrm{a}}$ & $3.04 \pm 0.04^{\mathrm{a}}$ & $3.0 \pm 0.03^{a}$ \\
\hline Globulin(g/dl) & $1.35 \pm 0.07^{c}$ & $1.53 \pm 0.07^{a}$ & $1.52 \pm 0.09^{a}$ & $1.4 \pm 0.09^{b}$ \\
\hline T. lipids (mg/dl) & $667 \pm 8.9 c$ & $729 \pm 7.02^{a}$ & $683.06 \pm 10.63^{b}$ & $748.2 \pm 15.35^{a}$ \\
\hline Triglyceride(mg/dl) & $157.7 \pm 2.86^{c}$ & $181.3 \pm 6.9^{b}$ & $171.45 \pm 3.14^{b}$ & $188 \pm 7.8^{a}$ \\
\hline Cholesterol(mg/dl) & $154.7 \pm 0.39 c$ & $162 \pm 1.0^{b}$ & $161.5 \pm 0 . .^{b}$ & $165 \pm 0.5^{\mathrm{a}}$ \\
\hline ALT (u/ml) & $51.85 \pm 0.8^{c}$ & $57.03 \pm 0.8^{b}$ & $53.3 \pm 0.2^{c}$ & $58.91 \pm 0.8^{a}$ \\
\hline AST (u/ml) & $104.5 \pm 1.02^{c}$ & $116.8 \pm 1.4^{b}$ & $107.5 \pm 1.28^{c}$ & $124.7 \pm 0.33^{\mathrm{a}}$ \\
\hline Alk. Phosphatase (IU/L) & $96.8 \pm 0.57^{c}$ & $102.2 \pm 0.53^{b}$ & $98.6 \pm 0.3^{b}$ & $116.6 \pm 0.62^{a}$ \\
\hline T.antioxidant(mM / L) & $1.22 \pm 0.05^{d}$ & $1.74 \pm 0.02^{\mathrm{a}}$ & $1.4 \pm 0.02^{c}$ & $1.61 \pm 0.02^{b}$ \\
\hline $\mathrm{T} 4(\mathrm{nmol} / \mathrm{L})$ & $52.78 \pm 0.87^{d}$ & $87.15 \pm 0.9^{b}$ & $68.13 \pm 0.8^{c}$ & $97.45 \pm 0.6^{a}$ \\
\hline
\end{tabular}

$a, b, c$, means with different superscripts within the same row are statistically different at $(p \leq 0.05)$.

oxide $2 \mathrm{~g} / 10 \mathrm{~kg}$ ration. The increases in total proteins, albumin, and globulin levels may result from increased muscle mass by exogenous CAM and or Zn. CAM serves as a stimulus of protein synthesis and muscle hypertrophy or reduced protein catabolism. Studies by Dilger et al. (2013) support this theory that CAM is an end-product of contraction; its' supplementation enhanced muscle fiber size and increased lean body mass. On the other hand, $\mathrm{Zn}$ is necessary for many physiological functions, including growth and protein synthesis; its' supplementation enhanced fat absorption, improved appetite, metabolism of carbohydrates, proteins, lipids, and many essential biochemical processes of chickens, Suttle (2010).

Related to lipids profile: plasma total lipids, cholesterol and triglycerides showed an elevation in all treated groups compared with the control. $\mathrm{Zn}$ and $\mathrm{CMH}$ in combination, was significantly $(p \leq 0.05)$ higher in plasma lipid profile compared to all other groups. These results disagree with Uyanik et al. (2001), who reported that $\mathrm{Zn}$ decreased cholesterol, triglycerides. CAM supplementation has also been shown to lower total plasma cholesterol and triglycerides, Earnest et al. (1996). The elevation in lipid profile may result from increased fat absorption as shown by Bartlett \& Smith (2003). In addition, the major role of $\mathrm{CMH}$ is in energy metabolism through PCr, as shown by Wyss \& Daouk (2000).

The results of plasma ALT, AST and alkaline phosphates (ALP) enzyme activities revealed significant increase in all treated groups compared to the control group and the increment was more effective and elevated when $\mathrm{Zn}$ was combined with $\mathrm{CMH}$ in the drinking water of chicks. This finding is inconsistent with Fazilati (2013) who reported that nano-ZnO, up to $200 \mathrm{mg} / \mathrm{kg}$ diet showed significant increase in ALT and AST activities in male rats. Similarly, Al-Daraji and Amen (2011) reported an increase in ALP activity with Zn supplementation. Nagalakshmi et al. (2015) showed that the ALP activity increased linearly with gradual increase in organic $\mathrm{Zn}$ supplementation higher than Zn supplemented from the inorganic source. $Z n$ being an integral component of ALP, higher bioavailability of organic source might have resulted in the increased ALP activity. Fathi et al. (2016) showed that nano-ZnO supplemented $20 \mathrm{mg} / \mathrm{kg}$ diet of the broilers, increased ALP activity with no significant effect on ALT and AST activates compared with the control group. These findings are in disagreement with those mentioned by Persky and Brazeau (2001) who reported that $\mathrm{CMH}$ supplementation had no effect on hepatic function as indicated by no changes in blood liver enzymes (i.e., ALT and AST). Zn also was shown to reduce both of these enzymes to the range of normal level, which represent the non-pathological metabolism of the liver and heart. Ahmadi et al. (2014), reported that nanoZnO had no significant effects on ALT and AST activities in serum of broilers. Although the values of serum levels of ALT, AST and ALP activity in chicks treated with $\mathrm{Zn}$ and $\mathrm{CMH}$ each alone were different, they were all within the normal range value and can be correlated with better function of the liver and appear nonpathological metabolism of the liver and heart which reflect better health of local Balady chicks subjected to this study. The changes in the serum transaminases level may depend on the rate of protein metabolism, Guyton \& Hall (2006). In addition, increased ALP activity may be a result of increased plasma concentrations of cholesterol in treated groups, Table 8. On the other hand, the higher levels of ALT, AST and ALP activity recorded in the serum of the chicks treated with $\mathrm{Zn}$ and $\mathrm{CMH}$ combined, among treatment groups, act 
as a hepatocellular damage indicator Bloom (2002). Any abnormal increase in serum levels of ALT, AST and ALP activity may imply in liver damage. Therefore, the relatively stable levels of these enzymes may be associated with hepatoprotective effects. Furthermore, the activities of serum ALP, ALT and AST enzymes could be important in the diagnosis of diseases as well as in the investigation and thorough assessment of feed, drugs and extracts used in the treatment as these could give indications of progressive toxicity long before the actual manifestation of the toxic effects, Bloom (2002). Moreover, increased serum ALP, ALT and AST activities have all been associated with physiological stressful condition.

AST and ALT usually appear in serum when there is damage to the liver and muscle tissues caused by excessive stress, Uyanik et al. (2001). Concerning to plasma total antioxidant capacity (T-AOC), our result revealed that there was significant elevation in plasma T-AOC in treated groups than the control. Zn group was significantly $(p \leq 0.05)$ higher in plasma total antioxidant than all other groups. These results totally coincided with the observations of Zhao et al. (2104) and Fawzy et al. (2016) who reported that serum T-AOC increased_significantly in Zn oxide $2 \mathrm{~g}$ $/ 10 \mathrm{~kg}$ diet supplemented broilers as compared with the control. Fathi et al. (2016) showed that nano-ZnO supplemented $20 \mathrm{mg} / \mathrm{kg}$ diet of the broilers improved the bird's antioxidant status compared with the control group. Liu et al. ${ }^{47}$ showed also that Zn Supplemental $0.9 \mathrm{~g} / \mathrm{kg}$ diet resulted in promoting antioxidant ability and activities of broilers.

The elevation in plasma T-AOC of chicks treated with $\mathrm{CMH}$ are in disagreement with those mentioned by Wang et al. (2015), who showed that $\mathrm{CMH}$ supplementation 0.6-1.2 g/kg diet does not offer any significant protection via directly reducing free radicals, muscle lipid peroxidation or increased antioxidant capacity of transported broilers in summer. Michiels et al. (2012) also showed that plasma total antioxidant capacity, was reduced by $\mathrm{CMH}$ supplementing 0.6$1.2 \mathrm{~g} / \mathrm{kg}$ broilers diet. Zhang et al. (2014) reported that the protective effect of $\mathrm{CMH}$ supplementation for maintaining meat quality in transported broilers is mainly related to its beneficial effect for producing more muscle PCr to produce ATP, and thus reduce the muscle glycolysis, rather than its antioxidant activity.

The total antioxidant capacity in the body related mainly to the dynamic balance of active oxygen, where T-AOC is an integrative factor reflecting the status of all the antioxidants in serum and body fluids. Hepatic damage may lead to a reduction in T-AOC Zhao et al. (2014). Moreover, $\mathrm{Zn}$ is considered a component of more than 300 enzymes and can manipulate oxidative processes. Researcher Niles et al. (2008) showed that $\mathrm{Zn}$ acts as an antioxidant to reduce cell membrane damage due to free radicals.

The elevation in plasma T-AOC of the chicks in the group treated with $\mathrm{Zn}$ higher than the $\mathrm{CMH}$ group, may be a result from $\mathrm{Zn}$ being considered a major part of the antioxidant enzyme superoxide dismutase, which protects the body from harmful effects of 'reactive oxygen species' as reported by Niles et al. (2008). Zn serves as a part of various enzyme systems within the avian body, Park et al. (2004). It is believed that Zn supplementation induces antioxidant effects to prevent oxidative DNA damage and mutagenesis, suppress oxidative stress such as toxicity of certain drugs and ethanol toxicity by the stimulation of certain substances which have antioxidant properties. Therefore, it can be concluded that Zn supplementation positively correlates with the bird's antioxidant status and may play a vital role in the maintenance of superior health.

Plasma concentration of thyroxin $\left(T_{4}\right)$ in treated chicks with $\mathrm{Zn}$ and or CAM supplementation was significantly higher $(p \leq 0.05)$ than those of chicks in the control group. Similar result was obtained by Michiels et al. (2012) who showed significant increase in plasma level of thyroid hormones with $\mathrm{CMH}$ supplementing 0.6-1.2 g/kg diet of broiler chickens. Depending on the previous results, we are not forgetting that $\mathrm{Zn}$ and or CAM also improved the growth rate of treated chicks which could be logically related to the increased plasma concentrations of the active form of thyroid hormone. The elevation in concentration of thyroxin $\left(T_{4}\right)$ in treated chicks may result from $\mathrm{Zn}$ and or CAM supplementation affecting a number of physiological and metabolic processes and the positive correlation between thyroxin and body weight. Persky \& Brazeau (2001) reported that thyroid hormones increased creatine content into skeletal muscle up to 3-fold relative to controls. Zhao et al. (2014) observed that $\mathrm{Zn}$ deficiency leads to failure of growth and poor development of gonadal functions. Dönmez et al. (2001) observed that serum free thyroxin levels increased significantly during adequate $\mathrm{Zn}$ period.

\section{CONCLUSION}

$\mathrm{Zn}$ and $\mathrm{CMH}$, alone or in combination in the drinking water had improved the physiological, productive traits of Balady chicks. The best significant 
results of performance were recorded for the group supplemented with $\mathrm{Zn}$ and $\mathrm{CMH}$ combined, compared with those of other treatments. Moreover, serological data from the present study showed the effectiveness of " $\mathrm{Zn}$ and or CAM" supplementation, they stimulate a protective immune response which sufficiently and positively correlate with the bird's antioxidant status.

\section{REFERENCES}

Ahmadi F, Ebrahimnezjad Y, Ghiasighalehkandi J, Maheri Sis N. The effect of dietary Zinc oxide Nano-particles on antioxidant status and serum enzymes activity in broiler chickens during stater stage. Proceedings of the International Conference on Biological, Civil and Environmental Engineering; 2014 Mar 17-18; Dubai, UAE; (2014).

Al-Daraji HJ Amen MHM. Effect of dietary zinc on certain blood traits of broiler breeder chickens. International Journal Poultry Research 2011;10(10):807-813.

Ayman E, El-Edel MAT, El-Lakany HF, Shewita RS. Growth performance and immune response against Newcastle and avian influenza vaccines in Egyptian chicken strains. Global Veterinaria 2012;9(4):434-440.

Bahakaim ASA, Hmat A, Abdel Magied MH, Sahar OSO, Amal NY, et al. Effect of using different levels and sources of zinc in layer's diets on egg zinc enrichment. Egyptian Poultry Science 2014;(34):39-56.

Bartlett, JR, Smith MO. Effects of different levels of zinc on the performance and immunocompetence of broilers under heat stress. Poultry Science 2003;82:1580-1588.

Bloom S. Abnormal liver function test in an asymptomatic patient. In: Bloom S, editor. Practical gastroenterology. London: Martin Dunitz; 2003. p.503-506.

Carvalho CMC, Fernandes EA, Carvalho AP, de, Maciel MP, Caires RM, Fagundes NS. Effect of creatine addition in feeds containing animal meals on the performance and carcass yield of broilers. Revista Brasileira de Ciência Avícola 2013;15(3):169-286.

Coles EH. Veterinary clinical pathology. $4^{\text {th }}$ ed. Philadelphia: W.B. Saunders Company; 1986.

Dacie J, Lewis S. Practical hematology. $7^{\text {th }}$ ed. Londres: Churchill Livingstone; 1991.

Dilger RN, Bryant-Angeoni K, Payne RL, Lemme A, Parsons CM. Dietary guanidino acetic acid is an efficacious replacement for arginine for young chicks. Poultry Science 2013;92:171-177.

Dönmez HH, Effects of increasing zinc supplementation in drinking water on growth and thyroid gland function and histology in broiler chicks. Deutsche Tierarztliche Wochenschrift 2001; 109(10):438-442.

Earnest, CP, Almada AL, Mitchell TL. High performance capillary electrophoresis- pure creatine monohydrate reduces blood lipids in men and women. Clinical Science 1996;91:113-118.

Enaiat MM, Amina AS, Eman MA. A comparative study of productive and physiological performance between two local strains of chicks. Egyptian Poultry Science 2010;30(I): 297-316.

Ezzati MS, Bozorgmehrifard MH, Bijanzad P, Rasoulinezhad S, Moomivand $\mathrm{H}$, Faramarzi S, et al. Effects of different levels of zinc supplementation on broilers performance and immunity response to Newcastle disease vaccine. European Journal of Experimental Biology 2013;3(5):497-501.
Fathi M, Haydari M Tanha T. Effects of zinc oxide nanoparticles on antioxidant status, serum enzymes activities, biochemical parameters and performance in broiler chickens. Journal of Livestock Science and Technologies 2016;4(2):7-13

Fawzy MM, El-Sadawi HA, El-Dien MH, Mohamed WAM. Hematological and biochemical performance of poultry following zinc oxide and sodium selenite supplementation as food additives. Annals of Clinica Pathology 2016;4(4):1076.

Fazilati M. Investigation toxicity properties of zinc oxide nanoparticles on liver enzymes in male rat. European Journal of Experimental Biology 2013:3:97-10

Feng J, Ma WQ, Niu HH, Wu XM, Wang Y, Feng J. Effects of zinc glycine chelate on growth, hematological, and immunological characteristics in broilers. Biological Trace Element Research 2010;133:203-211.

Gruber K, Rink L. The role of zinc in immunity and inflammation In: Calder PC, Yaqoob P, editor. Diet immunity and inflamation. Cambridge: Woodhead Publishing Co.; 2013. p.123-156.

Guimarães FL. Role of the phosphocreatine system on energetic homeostasis in skeletal and cardiac muscles. Einstein (São Paulo) 2014;12:126-131.

Guyton AC, Hall JE.Textbook of medical physiology. 11 $1^{\text {th }}$ ed. Philadelphia: W.B. Saunders; 2006.

Halle I, Henningm M, Kohler P. Studies of the effects of creatine on performance of laying hens, on growth and carcass quality of broilers Landbauforschung Volkenrode 2006;56(1/2): 11-18.

Harrison GJ, Harrison LR. Clinical avian medicine and surgery. Philadelphia: WB Saunders Co; 1986

Heckert RA, Estevez I, Russek-Cohen E, Pettit RR. Effects of density and perch availability on the immune status of broilers. Poultry Science 2002;81:451-457.

Hudson BP, Dozier WA, Wilson JL, Sander JE, Ward TL. Reproductive performance and immune status of caged broiler breeder hens provided diets supplemented with either inorganic or organic sources of zinc from hatching to 65 wk of age. Journal of Applied Poultry Research 2004;13:349-359.

King DJ, Seal BS. Biological and molecular characterization of Newcastle disease virus (NDV) field isolates with comparisons of reference NDV strains and pathogenicity chicken or embryo passage of selected isolates. Avian Diseases 1998;42:507-516.

Lemme A, Gobbi R, Helmbrecht A, Van Der Klis JD, Firman J, Jankowsk $J$, et al. Use of guanidino acetic acid in all-vegetable diets for turkeys. Proceeding of the $4^{\text {th }}$ Turkey Science and Production Conference, 2010; Cheshire. Macclesfield, UK: Turkeytimes; 2010. p.57-61.

Lindahl G, Youngj F, Oksbjerg N, Ersenh J. Influence of dietary creatine monohydrate and carcass cooling rate on colour characteristics of pork loin from different pure breeds. Meat Science 2006;72:624-634.

Liu ZH, Lu L, Wang RL, Lei HL, Li SF, Zhang LY, et al. Effects of supplemental zinc source and level on antioxidant ability and fat metabolism-related enzymes of broilers. Poultry Science 2015;94:2686-2694.

Michiels J, Maertens L, Buyse J, Lemme A, Rademacher M, Dierick NA et al. Supplementation of guanidinoacetic acid to broiler diets: Effects on performance, carcass characteristics, meat quality, and energy metabolism. Poultry Science 2012;91:402-412

Mousavi S, Afsar A, Lotfollahian H. Effects of guanidinoacetic acid supplementation to broiler diets with varying energy contents. Journal of Applied Poultry Research 2013;22:47-54.

Nagalakshmi D, Sridhar K, Parashuramulu S. Replacement of inorganic zinc with lower levels of organic zinc (zinc nicotinate) on performance, 
hematological and serum biochemical constituents, antioxidants status and immune responses in rats. Veterinary World 2015;8(9):1156-1162.

Niles BJ, Clegg MS, Hanna LA, Chou SS, Momma TY, Hong H, et al. Zinc deficiency induced iron accumulation, a consequence of alterations in iron regulatory protein-binding activity, iron transporters and iron storage proteins. Journal of Biological Chemistry 2008;283:5168-5177.

NRC - National Research Council. Nutrient requirements of poultry. $9^{\text {th }}$ ed. Washington: National Academy Press; 1994.

Osman AMR, Ragab MS. Performance and carcass characteristics of broiler chicks fed diets supplemented with commercial zinc-methionine. Proceedings of the $4^{\text {th }}$ World Poultry Conference; 2007; Sharm ElSheikh, Egypty; 2007. p.347-365.

Park S, Birkhold YS, Kubena L, Nisbet D, Ricke S. Review on the role of dietary zinc in poultry nutrition, immunity, and reproduction. Biological Trace Element Research 2004;101:147-163.

Persky AM, Brazeau GA. Clinical pharmacology of the dietary supplement creatine monohydrate. Pharmacological Reviews 2001;53:161-176.

Prasad AS. Clinical, immunological, anti-inflammatory and antioxidant roles of zinc. Experimental Gerontology 2008;43:370-377.

Sahraei M, Janmmohamadi $H$, Taghizadeh A. Estimation of the relative bioavailability of several zinc sources for broilers fed a conventional corn-soybean meal diet. Journal of Poultry Science 2013;50:53-59.

Sajadifar SA. Effect of high levels of zinc on antibody response and total white blood cell in broiler chicks Vaccinated against coccidiosis. Biological Journal of Armenia 2012;4(64):94-96.

SAS - Statistical Analysis System. SAS/STAT® 9.2. User's guide. Cary: SAS Institute Inc.; 2008.

Sonaiya EB, Swan SEJ. Small-scale poultry production. Animal production and health manual [technical guide]. Rome: FAO; 2004.
Sunder GS, Panda AK, Gopinath NCS, Rama Rao SV, Raju MVLN, Reddy MR et al. Effects of higher levels of zinc supplementation on performance, mineral availability, and immune competence in broiler chicks. Journal of Applied Poultry Research 2008;17:79-86.

Suttle NF. Mineral nutrition of livestock. Wallingford: CABI Publishing; 2010.

Taha AE, Abd El-Ghany FA, Sharaf MM. Strain and sex effects on productive and slaughter performance of developed local Egyptian and Canadian chicken strains. Egyptian Poultry Science 2010;30: 1059-1072.

Uyanik F, Eren M, Tuncoku G. Effects of supplemental zinc on growth, serum glucose, cholesterol, enzymes and minerals in broilers. Pakistan Journal of Biological Sciences 2001;4:745-747.

Wang XF, Zhu XD, Li YJ, Liu Y, Li JL, Gao F, et al. Effect of dietary creatine monohydrate supplementation on muscle lipid peroxidation and antioxidant capacity of transported broilers in summer, Poultry Science 2015;94:2797-2804

WYSS M, Daouk KR. Creatine and creatinine metabolism. Physiological Reviews 2000;80(3):1107-1213.

Yang XJ, Sun XX, Li CY, Wu XH, Yao JH. Effects of copper, iron, zinc, and manganese supplementation in a corn and soybean meal diet on the growth performance, meat quality, and immune responses of broiler chickens. Journal of Applied Poultry Research 2011;20:263-271.

Zhang L, Li JL, Gao T, Lin M, Wang XF, Zhu XD, et al. Effects of dietary supplementation with creatine monohydrate during the finishing period on growth performance, carcass traits, meat quality and muscle glycolytic potential of broilers subjected to transport stress. Animal 2014:8:1955-1962.

Zhao CY, Tan SX, Xiao XY, Qiu SX, Pan JQ, Tang ZX. Effects of dietary zinc oxide nanoparticles on growth performance and antioxidative status in broilers. Biological Trace Element Research 2014;160:361-367. 
